\title{
E daí surge o PSF como uma continuidade $e$ um aperfeiçoamento do PACS
}

\author{
And then PSF appears, as an extension and an improved version of PACS
}

Emerson Elias Merhy 1

Com a frase acima, citada no sexto parágrafo do item que trata da reforma sanitária brasileira, os autores deixam antever o grau de profundidade com que tratarão o tema.

Entendo que um tema candente como esse - o Programa de Saúde da Família e os desafios para a formação profissional, tratado de modo genérico, provoca um debate que não faz juz ao conjunto dos atores sociais envolvidos $e$ aos conteúdos que levantam em suas argumentações.

O PSF não é uma questão tão óbvia assim. E, também, necessariamente não é algo para ser incriminado ou defendido, como se fôssemos torcedores de times esportivos.

Expõe, na sua aparição tão maciça no interior dos projetos de amplos setores tecnopolíticos que compõem o variado processo da reforma sanitária brasileira, instigantes possibilidades analíticas e grandes oportunidades para se melhorar os graus de compreensão dos labirínticos caminhos que tem, diante de si, o setor saúde. Particularmente, enquanto campo de reorganização tecnológica nos modos de se produzir saúde.

Caminha-se, com ele, para modalidades mais complexas ou simples, na composição entre tecnologias materiais e não-materiais, implicadas com a produção, por exemplo, dos atos médicos?

O PSF compõe uma efetiva alternativa para responder aos distintos processos que vêm atuando na reestruturação produtiva do setor saúde?

Os objetos das práticas de saúde são ou não definidos de maneiras simples ou complexas? Será que estes objetos apresentam-se de modo evidente para os atos produtivos em saúde, isto é, seriam os objetos de ação dos trabalhos em saúde fáceis de serem apreendidos?

Quais territórios do conhecimento em saúde, como é o caso da epidemiologia e da vigilância em saúde, seriam mais do que suficientes para darem conta dos mesmos?

\footnotetext{
${ }^{1}$ Professor da Faculdade de Ciências Médicas da Universidade Estadual de Campinas, Unicamp. <emerhy@fcm.unicamp.br>
} 
Os autores ajudam a pensar sobre estas questões com seu texto?

Parece que não. Ao explicarem tudo de modo muito lógico, simples, levando o leitor a entender que o debate em torno do assunto - o PSF - é muito linear e desideologizado, ou mesmo sugerindo, sem o dizer, que qualquer um que queira problematizá-las, para além do que apresentaram, está querendo ver conflito onde não há.

Não consigo entender por que boa parte dos "sanitaristas" do Brasil têm desconhecido a rica produção da saúde coletiva, que vem há longa data mostrando que saúde é uma "coisa" complexa, que envolve eixos temáticos fundamentais para a sua compreensão, dos quais um debate sobre o PSF não pode fugir.

Ao contrário, considero que o mesmo se constitui hoje em um rico analisador, no campo da saúde, de certas questões, desde que reflexivamente se expusesse o mesmo a uma discussão sobre: a política pública e a reforma do Estado; as modalidades tecnológicas de organização dos processos de trabalho e a reestruturação produtiva do setor saúde; os modelos de assistência à saúde; ou mesmo, os tipos de debate que as distintas propostas para a ação na reforma sanitária têm travado.

Por isso, tomo como necessário que qualquer texto, que defenda o tema ou não, procure abrir reflexões adequadas, ou pelo menos pontuá-las, sem mascaramentos em pensamentos lineares, que só servem para justificar decisões tomadas "a priori", como inevitáveis.

Não exigiria dos autores que tratassem de temas tão ricos em um texto ensaístico e delimitado, como esse, mas imagino que não é possível reduzir de modo tão genérico o debate, como fazem, desconhecendo inclusive produções problematizadoras sobre o tema, no Brasil.

A CINAEM não é para ser citada só em um curto momento ao lado do tema do provão. As várias experiências de reformas do ensino médico que o país vem vivenciando não podem ser desconhecidas, como se não houvesse bibliografia sobre o assunto. O silêncio sobre os UNI $e$ a possibilidade de um diálogo construtivo com o projeto de formação profissional que apresenta é incompreensível.

O texto teve o mérito de me instigar a responder por quê o movimento santinário não adotou esta proposta antes, ou seja, se o PSF é tão poderoso como instrumento de mudança, como vem sendo apresentado, por que não vimos isso? Ou será que éramos mais exigentes e a proposta nos aparecia muito simples para nossas ambições, anteriores?

Quando olho um hipotético quadro das necessidades de saúde, que o movimento da reforma sanitária brasileira permite desenhar, tenho quase certeza disso. O PSF pode ser um bom instrumento para a ação em redes de serviços locais, mas é uma modalidade tecnológica de produção de atos de saúde insuficiente para dar conta do que sempre imaginamos como nossos objetos de ação, na saúde.

De uma maneira bem sintética, considerando a centralidade dos usuários, individuais e coletivos, por serem os portadores e os que expressam o mundo das necessidades de saúde, pode-se imaginar algumas das possíveis manifestações deste "mundo-objeto" das ações de saúde: 


\begin{tabular}{|l|l|}
\hline \multicolumn{1}{|c|}{$\begin{array}{c}\text { Necessidades de saúde de } \\
\text { indivíduos e/ou grupos }\end{array}$} & Algumas idéias sobre os seus significados \\
\hline $\begin{array}{l}\text { Necessidade de boas condições de } \\
\text { vida }\end{array}$ & $\begin{array}{l}\text { boa moradia, alimentação, transporte, lazer, viver em } \\
\text { processos sociais de inclusão }\end{array}$ \\
\hline $\begin{array}{l}\text { necessidade de ser alguém singular } \\
\text { com direito à diferença }\end{array}$ & $\begin{array}{l}\text { ser sujeito de direitos e cidadão, ser igual, ser nominal, } \\
\text { ser respeitado em suas necessidades "especiais", ser } \\
\text { incluído }\end{array}$ \\
\hline $\begin{array}{l}\text { garantia de acesso a todas as } \\
\text { tecnologias que melhorem e } \\
\text { prolonguem a vida }\end{array}$ & $\begin{array}{l}\text { sempre que for necessário poderá e deverá consumir } \\
\text { serviços de saúde que possam impactar e qualificar seu } \\
\text { modo de andar na vida }\end{array}$ \\
\hline $\begin{array}{l}\text { necessidade de ser acolhido e ter } \\
\text { vínculo com um profissional ou equipe } \\
\text { (sujeitos em relação) }\end{array}$ & $\begin{array}{l}\text { poder acessar e ser recebido e bem acolhido em } \\
\text { uma referência de responsabilização pelo seu } \\
\text { atendimento }\end{array}$ \\
\hline $\begin{array}{l}\text { Necessidade de autonomia e } \\
\text { autocuidado na escolha do modo de }\end{array}$ & $\begin{array}{l}\text { ser tratado como sujeito do saber e do fazer, em } \\
\text { produção, que irá a cada momento "operar" seu próprio } \\
\text { modo de andar na vida. }\end{array}$ \\
\hline
\end{tabular}

Sem dúvida, o PSF pode ter lugar. Mas, como fazer com propostas que o olham como " $\mathrm{A}$ " modalidade que irá conseguir, ao mesmo tempo, responder de modo positivo e otimista, a incorporação de todas as variáveis que estão envolvidas no desenho do quadro acima.

Uma das conseqüências que vejo é que a própria força que ele possa ter fica perdida ao ambicionar tanta intenção. Imagino, então, que o mais adequado é explorá-lo dentro de seus limites e colá-lo a um processo reflexivo, que vá além da sua natureza de receituário de práticas de saúde de pobre para pobre.

Incorporá-lo como uma das modalidades tecnológicas, que podem fazer parte da complexa ação das redes básicas de saúde, seria a melhor forma de potencializá-lo.

Por isso, politizar este debate é essencial, instigando os sujeitos envolvidos com a implantação do SUS a serem sujeitos reflexivos, e não sujeitos da adesão pura e simples. 